\title{
Unusual Extramedullary Recurrence and Renal Relapse Despite Complete Chimerysm after Allografting in $\mathrm{Ph}^{+}$ALL
}

\author{
Songul SEREFHANOGLU ${ }^{1}$, Hakan GOKER ${ }^{1}$, Dilek E. BAYDAR ${ }^{2}$, Aysegul UNER ${ }^{2}$, Mustafa ARICI ${ }^{3}$, \\ Ibrahim C. HAZNEDAROGLU ${ }^{1}$, Yahya BUYUKASIK ${ }^{1}$, Nilgun SAYINALP ${ }^{1}$, \\ Salih AKSU' ${ }^{1}$, Osman I. OZCEBE ${ }^{1}$ \\ ${ }^{1}$ Hacettepe University Faculty of Medicine, Department of Internal Medicine, Division of Hematology \\ ${ }^{2}$ Hacettepe University Faculty of Medicine, Department of Pathology \\ ${ }^{3}$ Hacettepe University Faculty of Medicine, Department of Internal Medicine, Division of Nephrology, Ankara, TURKEY
}

\begin{abstract}
Extramedullary recurrences with or without bone marrow involvement are reported in up to a half of leukemic relapses after bone marrow transplantation. Extramedullary relapse of acute lymphoblastic leukemia (ALL) in the kidney after allogeneic stem cell transplantation (allo-SCT) is rare. We herein, report an additional case with extramedullary recurrences and renal relapse after first-allografting for $\mathrm{Ph}+-$-acute lymphoblastic leukemia. He had no evidence of leukemia in his marrow demonstrating $98 \%$ full-donor chimerism while he had ALL relapse in his kidney.
\end{abstract}

Keywords: Acute Lymphoblastic leukemia, Renal relapse, Allogeneic stem cell transplantation, Chimerism

ÖZET

Allojenik Nakil Yapılan Ph+ ALL Vakasında Tam Kimerizime Rağmen Ender Görülen Ekstramedüller Nüks ve Renal Relaps

Kemik iliği nakli sonrası relaps olan lösemik hastaların yaklaşık yarısında kemik iliği tutulumu olsun veya olmasın ekstramedüller nüksler bildirilmiştir. Allojenik kök hücre nakli sonrası akut lenfoblastik löseminin böbrek relapsı nadirdir. Biz burada, Ph+-akut lenfoblastik lösemili bir hastada ilk allojenik nakil sonrası ekstramedüller nüks ve renal relaps olan ilave bir vakayı sunuyoruz. Böbreğinde ALL relapsı olduğu halde hastanın kemik iliğinde \%98 oranında tam verici kimerizmi olup kemik iliğinde lösemik tutulumu yoktu.

Anahtar Kelimeler: Akut lenfoblastik lösemi, Böbrek relapsı, Allojenik kök hücre nakli, Kimerizim

\section{INTRODUCTION}

Leukemic cells can essentially infiltrate any organ of the human body. Leukemic infiltration is most frequently seen in bone marrow, lymph nodes, spleen and liver that are rich in lymphoid tissue. ${ }^{1}$ Extramedullary recurrences with or without bone marrow invol- vement are reported in up to a half of leukemic relapses after bone marrow transplantation. The kidney is the most frequent extramedullary site of leukemic infiltration, with these findings identified in $63 \%$ of autopsies performed on patients who died with either lymphoid or myeloid leukemia. ${ }^{2}$ 
But, extramedullary relapse of acute lymphoblastic leukemia (ALL) in the kidney after allogeneic stem cell transplantation (allo- SCT) is rare after either bone marrow transplantation or chemotherapy. In adult patient cohorts isolated or combined extramedullary relapse after allo-HSCT is associated with a better outcome than medullary relapse..$^{3-4}$ Also, extramedullary versus medullary relapse seems to be favoured by chronic graft versus host disease and a long time interval between transplantation and relapse. ${ }^{4}$

Isolated renal relapse after allogeneic peripheral hematopoietic stem cell transplantation (allo-PHSCT) in adult with $\mathrm{Ph}^{+}$acute lymphoblastic leukemia (ALL) is a rare condition. Generally, in ALL, the sites most frequently affected by extramedullary relapse are the central nervous system (CNS) and the testicles. There are single reports on relapses affecting abdominal lymph nodes, bones, thoracic wall, mediastinum, orbit/ upper eyelid, retro-orbital tissue, iris, heart and breast. ${ }^{5-13} \mathrm{We}$, herein, report a case with relapsed $\mathrm{Ph}^{+} \mathrm{B}$-precursor ALL, who underwent alloPHSCT from HLA-identical siblings and suffered a histopathologically proven isolated bilateral renal relapse 2 years post alloHSCT.

\section{CASE REPORT}

A 45-year old male patient was diagnosed $\mathrm{Ph}+$ preB-ALL in August 2005. On admission, laboratory investigations showed a total leukocyte count of $15.9 \mathrm{x}$ $10^{9}$ L-1 (differential blood count: neutrophils $20 \%$, lymphocytes $12 \%$, monocytes $3 \%$ and blasts $65 \%$ ), hemoglobin $7.4 \mathrm{~g} \mathrm{dL}-1$, platelet count $50 \times 10^{9} \mathrm{~L}-1$, lactate dehydrogenase of 1530 (N, 250-480). A bone marrow aspirate biopsy is performed which revealed TdT, CD19 and CD20 positive acute lymphoblastic leukemic infiltration of the marrow. A flow cytometric investigation showed that $\mathrm{CD} 19, \mathrm{CD} 20, \mathrm{CD} 22$, CD45, HLA-DR and TDT positive. Conventional cytogenetic and PCR analysis for $\mathrm{t}(9 ; 22)$ gene product was positive.

Following the diagnosis of ALL, combination chemotherapy using high dose cytarabine and methotrexate has been initiated. The patient's disease did not respond to one cycle high dose cytarabine and methotrexate chemotherapy at the time of diagnosis. Complete remission was obtained with the hyperC-
VAD (cyclophosphamide, vincristine, adriamycin and dexamethasone) combination chemotherapy. Eight courses consecutive high dose cytarabine-methotrexate and hyperCVAD were received. He relapsed in the bone marrow two months after chemotherapy and a second complete remission was obtained with the ALL-CALGB (cyclophosphamide, L-asparaginase, vincristine, daunorubicine and dexamethasone) combination chemotherapy and imatinib mesylate. He underwent first allogeneic matched- sibling peripheral blood stem cell transplantation (alloPBSCT) in April 2006, during his first complete remission. Busulfan $0.8 \mathrm{mg} / \mathrm{kg}$ every $6 \mathrm{~h}$ for 8 doses, fludarabine $30 \mathrm{mg} / \mathrm{m}^{2} /$ day for 6 days and antithymocyte globulin $2.5 \mathrm{mg} / \mathrm{kg} /$ day for 4 days were used as the reduced intensity conditioning regimen. The patient received GVHD prophylaxis consisting of cyclosporine A (CsA) $5 \mu \mathrm{g} / \mathrm{kg} /$ day by continuous intravenous infusion starting on day -2 and switched to the p.o. formulation the patient was able to tolerate medication p.o. and stopped after 100 days (absence of GVHD). And patient received methotexate at a dose of $15 \mathrm{mg} / \mathrm{m}^{2}$ on day +1 and $10 \mathrm{mg} / \mathrm{m}^{2}$ on days +3 and +6 and +11 post transplant. The patient had no any acute or chronic graft-versus-host disease (GVHD). Bone marrow examinations 1, 3, 5, 6, 7, 8, 10,12 , and 14 months after HSCT showed complete remission morphologically, by flow cytometry and had complete donor chimaerism.

He was admitted with a renal failure and massive bilateral pleural effusion, two years after his first alloPBSCT. Laboratory evaluation revealed a blood urea nitrogen level of $30 \mathrm{mg} / \mathrm{dl}$ and a serum creatinine level of $2.9 \mathrm{mg} / \mathrm{dl}$. Five days later, the patient's serum creatinine level had increased to $5.5 \mathrm{mg} / \mathrm{dl}$, and one week after initial presentation he was admitted to hospital for evaluation of acute renal failure. An ultrasound of his kidneys revealed marked bilateral renal enlargement with echogenic parenchyma. The right kidney measured 16 × 9 × $8.5 \mathrm{~cm}$ with $29 \mathrm{~mm}$ cortical thickness, and the left kidney measured $18 \mathrm{x}$ $9.5 \times 9 \mathrm{~cm}$ with $30 \mathrm{~mm}$ cortical thickness. A CT scan of the thorax showed bilaterally pleural effusion (7 $\mathrm{cm}$ ) and abdomen also showed $20 \times 8 \mathrm{~mm}$ aortico-caval intra-abdominal lymphadenopathy. Biopsy revealed dense interstitial infiltration of renal tissue by malignant lymphoid cells. They had small amounts 


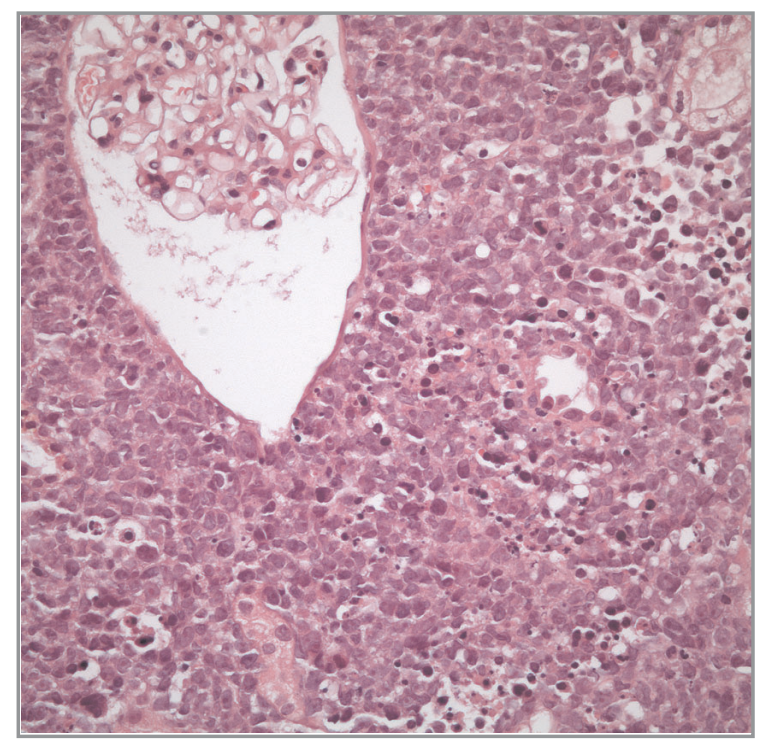

Figure 1. Diffuse interstitial infiltration of renal tissue by the malignancy widely separating nephronal elements and effacing the normal architecture. Neoplastic cells have dispersed chromatin, small nucleoli, narrow amphophilic cytoplasm and high mitotic rate $(\mathrm{H}-$ Ex 400).

of amphophilic cytoplasm and contained large nuclei with small nucleoli. Mitotic figures were numerous. Immunohistochemistry indicated precursor B cell phenotype with diffuse expression of CD20 and TdT (terminal deoxynucleotidyl transferase) in the neoplasm. The neoplastic cells were also positive for CD79a and CD10, but negative for CD3. The glomeruli were normal microscopically and negative with immunofluorescence. A bone marrow biopsy was normacellular. Bone marrow cells were shown to be of $98 \%$ of donor origin. The pleural effusion was infiltrated atypical lymphoid cells, and flow cytometric studies of pleural effusion showed a population of $\mathrm{T}$ and B lymphoblasts that expressed CD3, CD5, CD7, CD19, CD20 and HLA-DR. Philadelphia chromosome and bcr-abl were negative by cytogenetics and by molecular biological analysis, respectively. Chimaerism analysis showed complete chimaerism $(98 \%$ donor type) at time of extramedullary relapse.

The acute renal failure was attributed to renal leukemic infiltration, the patients was given allopurinol for hyperuricemia and hydrated with alkalized intravenous fluids. Daily hemodialysis was initiated and was performed over three consecutive days. He was then started on a dasatinib consisted of $2 \times 70$ $\mathrm{mg} /$ day. Unfortunately the patient died of sepsis.

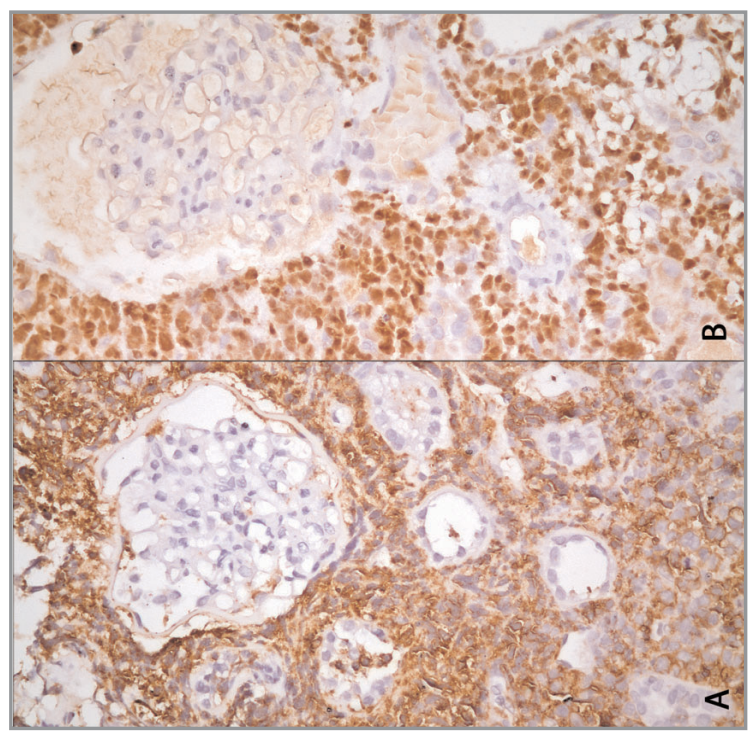

Figure 2. Lymphoblastic cells showing strong reaction for CD20 and Tdt. A. Immunohistochemistry, primary anti-CD20 antibody, $\mathrm{ABC} \times 400$; B. Immunohistochemistry, primary anti-Tdt antibody, $\mathrm{ABC} \times 400)$

\section{DISCUSSION}

Isolated renal relapse after allogeneic peripheral hematopoietic stem cell transplantation (allo-PBSCT) in adults with acute lymphoblastic leukemia (ALL) is a rare condition. Extramedullary relapse of acute leukemias following allo-PBSCT is common in adult patients with rates of extramedullary involvement documented in $40-50 \%$ of cases. ${ }^{3}$ The studies shown that isolated or combined extramedullary relapse is better outcome than medullary relapse. ${ }^{3-4}$ The mostfrequent sites of ALL involvement are skin, bone, soft tissue, lymph nodes, ovaries, retroperitoneum, tonsillar primary tumor, and mediastinum and biopsy is important for the diagnosis. Tumor infiltration of the kidney may occur, but accounts for renal insufficiency in only $1 \%$ of patients. ${ }^{14}$ Most isolated extramedullary relapses after allo-PBSCT for ALL occur in the central nervous system (CNS) and the testicles, while relapses to other localizations are exceedingly rare. A different pattern of relapse has been observed after allogeneic BMT for patients with leukemia. Compared with treatment using conventional chemotherapy alone, isolated extra-medullary relapse of disease appears to be seen more commonly after allogeneic BMT. Isolated extramedullary relapse of acute lymphoblastic leukaemia (ALL) with sparing of the marrow after allogeneic bone marrow transp- 
lantation (BMT) is a rare occurrence, and the mechanisms underlying the selective involvement of extramedullary sites remain undefined. In the literature, the possible mechanisms associated that the leukaemic cells are resistant to chemotherapy or a stronger putative graft-versus-leukaemia effect in the marrow as compared with peripheral tissues. ${ }^{5}$

Acute renal failure is unusual at the presentation of acute leukemia, and renal dysfunction more commonly occurs as a consequence of treatment for the leukemia. ${ }^{1}$ Several factors may disturb renal function in leukemia patients that are nephrotoxicity, metabolic changes arising from chemotherapy, radiotherapy, infections, treatment with nephrotoxic antibiotics, intravascular coagulopathy and infiltration of kidneys with leukemic cells. ${ }^{15-19}$ Acute renal failure due to leukemic cell infiltration into the kidney is rare in acute lymphoblastic leukemia after allogeneic-SCT, and this phenomenon might be related to kidney's role in embryonic hematopoiesis through the aorta-gonad-mesonephrons region. ${ }^{20-21}$ Tumor infiltration into the kidneys can occur, yet this accounts for renal insufficiency in only $1 \%$ of patients..$^{22}$ All of those relapses are associated with significant morbidity and mortality. Most relapses occur within the first 6-12 months, although disease-free survival curves do not begin to plateau until 24 months post-transplant.

The literature provides a significant decrease in post bone marrow transplantation nephropathy in adults with increasing shielding of the kidney. ${ }^{23-24}$ Because of this condition, they recommend renal shielding when doses higher than $10 \mathrm{~Gy}$ are applied. Although, Borg et al. demonstrated that a dose of 12 Gy at 2 Gy/fraction resulted in only 1 case of radiation nephritis in the 59 patients studied 24 months after the completion of TBI and BMT. And renal shielding was not used. Our patient did not receive TBI for conditioning regimen. The presence of graft-versushost disease has been shown to favour extramedullary relapse over medullary relapse. ${ }^{4}$ In our patient no signs of acute and chronic graft-versus-host disease was observed prior to nor at the time of extramedullary relapse.

A potential mechanism in the trafficking of leukaemia cells is the interaction of the chemokine receptor CXCR4, which is expressed on ALL cells, and its ligand stromal cell-derived factor-1 (SDF-1), produ- ced by stromal cells in bone marrow and extramedullary organs. ${ }^{25}$ As high expression of the chemokine receptor CXCR4 predicts extramedullary organ infiltration in ALL, Crazzolara et al. suggest that CXCR4 and its ligand play an essential role in extramedullary invasion..$^{25}$

We describe a rare presentation of extra-medullary relapse in an adult with Philadelphia chromosomepositive acute lymphoblastic leukemia who had undergone allogeneic bone marrow transplantation after first remission. In spite of enduring bone marrow remission, the patient experienced a local relapse in the kidneys within 2 years of the transplant. Extramedullary recurrences following allo-SCT for ALL usually occur in the 'sequestered sites', i.e. the testis and central nervous system. ${ }^{3}$ The nervous system and testis are known as 'sanctuary' sites for chemotherapy, because anti-cancer drugs do not usually penetrate into these organs. These relapses usually have a poor prognosis. In these patients effective treatment has not been defined and the GVL effect may be of little value for these lesions. ${ }^{26}$ The majority of relapses occur in the bone marrow. Nakayama et al. described isolated renal relapse after bone marrow transplantation in childhood leukemia in 1992. This is the first case in the adult patient whom had no evidence of leukemia on his marrow and $98 \%$ full-donor chimerism while he had $\mathrm{Ph}+\mathrm{ALL}$ relapse in his kidneys.

Due to the low incidence of localized extramedullary relapses, therapeutic strategies for these complications are not yet defined. GVL effect may be stronger in the marrow than in peripheral tissues. The prognosis is poor in general, but prolonged survival has been observed in some of these patients. With the preservation of donor's hematopoiesis in the recipient's marrow, the use of intensive chemotherapy followed by donor lymphocyte or stem cell re-infusion is a promising option.

\section{REFERENCES}

1. Suh WM, Wainberg ZA, de Vos $S$, et al. Acute lymphoblastic leukemia presenting as acute renal failure. Nat Clin Pract Nephrol 3: 106-110, 2007.

2. Kirshbaum JD, Preuss FA. Leukemia, a clinical and pathological study of 123 fatal cases in a series of 14,400 necropsies. Arch Intern Med 71: 777-792, 1943. 
3. Lee KH, Lee LH, Kim S, et al. High frequency of extramedullary relapse of acute leukemia after allogeneic bone marrow transplantation. Bone Marrow Transplant 26: 147-152, 2000.

4. Chong G, Byrnes G, Szer J, Grigg A. Extramedullary relapse after allogeneic bone marrow transplantation for haematological malignancy. Bone Marrow Transplant 26: 1011-1015, 2000.

5. Au WY, Lie AK, Liang R, Kwong YL. Isolated extramedullary relapse of acute lymphoblastic leukaemia after allogeneic bone marrow transplantation. Bone Marrow Transplant 24: 1137-1140, 1999.

6. Colombini A, Barzaghi A, Castagneto M, et al. Retroorbital late relapse in a child with leukaemia after allogeneic bone marrow transplantation. Acta Haematol 94:44-47, 1995.

7. Ueda S, Kanamori H, Sasaki S, et al. Isolated extramedullary relapse in knee joint after allogeneic bone marrow transplantation for Ph ALL. Bone Marrow Transplant 21: 319-321, 1998.

8. Wright TL, Bardy PG, Disney P, et al. Isolated cardiac recurrence of acute lymphoblastic leukemia characterized by $\mathrm{t}(11 ; 19)$ two years after unrelated allogeneic bone marrow transplantation. Cancer Genet Cytogenet 137: 146-149, 2002

9. Lawson SE, Darbyshire PJ. Use of donor lymphocytes in extramedullary relapse of childhood acute lymphoblastic leukaemia following bone marrow transplantation. Bone Marrow Transplant 22: 829-830, 1998.

10. Schafer $\mathrm{H}$, Bader $\mathrm{P}$, Kaiserling $\mathrm{E}$, et al. Extramedullary relapses at uncommon sites after allogeneic stem cell transplantation. Bone Marrow Transplant 26:11331135, 2000.

11. Au WY, Kwong YL, Lie AK, et al. Extra-medullary relapse of leukemia following allogeneic bone marrow transplantation. Hematol Oncol 17: 45-52, 1999.

12. Jaing $T H$, Hung IJ, Shih $L Y$, et al. Extramedullary relapse in the left proximal femur with Philadelphia chromosome positive acute lymphoblastic leukemia after allogeneic bone marrow transplantation. J Pediatr Hematol Oncol 25: 65-68, 2003.

13. Conter $\mathrm{V}$, D'Angelo $\mathrm{P}$, Rovelli $\mathrm{A}$, et al. Isolated breast relapse after allogeneic bone marrow transplantation for childhood acute lymphoblastic leukemia. Med Pediatr Oncol 20: 165-168, 1992.

14. Fer MF, McKinney TD, Richardson RL, et al. Cancer and the kidney: complications of neoplasm. Am J Med 71: 704-718, 1981.

15. Yetgin $\mathrm{S}$, Olgar Ş, Aras $\mathrm{T}$, et al. Evaluation of kidney damage in patients with acute lymphoblastic leukemia in long-term follow-up: value of renal scan. Am J Hematol 77: 132-139, 2004.

16. Hovi L, Koskimies O, Holmberg C, et al. Risk of progressive kidney damage after acute leukemia. Acta Paediatr Scand 78: 608-614, 1989.
17. Comerma-Coma MI, Sans-Boix A, Tuset-Adjuvar E, et al. Reversible renal failure due to specific infiltration of the kidney in chronic lymphocytic leukemia. Nephrol Dial Transplant 13: 1550-1552, 1998.

18. Munker R, Hill $\cup$, Jehn $\cup$, et al. Renal complications in acute leukemias. Haematologica 83: 416-421, 1998.

19. Dierzak E. Embryonic beginnings of definitive hematopoietic stem cells. Ann NY Acad Sci 872:256262, 1999.

20. Ohneda O, Fennie C, Zheng Z, et al. Hematopoietic stem cell maintenance and differentiation are supported by embryonic aorta-gonad-mesonephros regionderived endothelium. Blood 92: 908-919, 1998.

21. Bunchman TE, Gale GB, O'Connor DM, et al. Renal biopsy diagnosis of acute lymphoblastic leukemia. Clin Nephrol 38: 142-144, 1992.

22. Borg M, Hughes $\mathrm{T}$, Horvath $\mathrm{N}$, et al. Renal toxicity after total body irradiation. Int $\mathrm{J}$ Radiat Oncol Biol Phys 54: 1165-1173, 2002.

23. Lawton CA, Cohen EP, Murray KJ, et al. Long-term results of selective renal shielding in patients undergoing total body irradiation in preparation for bone marrow transplantation. Bone Marrow Transplant 20: 1069-1074, 1997.

24. Boueva A, Bouvier R. Precursor B-cell lymphoblastic leukemia as a cause of a bilateral nephromegaly. Pediatr Nephrol 20: 679-682, 2005.

25. Crazzolara R, Kreczy A, Mann G, et al. High expression of the chemokine receptor CXCR4 predicts extramedullary organ infiltration in childhood acute lymphoblastic leukemia. Br J Haematol 115: 545-553, 2001.

26. Seo S, Kami M, Honda $\mathrm{H}$, et al. Extramedullary relapse in the so-called 'sanctuary' sites for chemotherapy after donor lymphocyte infusion. Bone Marrow Transplant 25: 226-227, 2000.

\section{Correspondence}

Dr. Songul ŞEREFHANOĞLU

Hacettepe Üniversitesi Tıp Fakültesi

Dahiliye Anabilim Dalı

Hematoloji Bölümü

Samanpazarı, ANKARA / TURKEY

Tel: (+90.312) 3051543

e-mail: dr.songul1978@yahoo.com 